\title{
我々の行なった小览大腿骨頸部骨折の治療成績
}

\author{
熊本大学医学部整形外科 (主任 : 玉井達二教授) \\ 忽 那龍 雄 清 水寛 \\ 金田武 昭
}

\section{Results of Fracture of Femoral Neck in Children}

By

\author{
T. Kutsuna, Y, Shimizu \& T. Kaneda \\ Department of Orthopaedic Surgery \\ Kumamoto University Medical School
}

\begin{abstract}
The fracture in injury of the femoral neck is rare in children, and the prognosis of this fracture is bad since there are complications such as ensuing necrosis of the femoral head.

Nine cases of children with the fracture of the femoral neck have been on this radiographical and functional results of conservative treatment.

1) Union of the fractured bone was shown in all cases.

2) With seven cases one year or more after fracture, results of the treatment were good in five cases and bad in two cases. The prognosis the intertrochanteric fracture is good, but that of the cervicotrochanteric fracture bad.

3) Weight-bearing as well as the complete reposition and the fixation of the fracture is an important factor for prevention of the following complications
\end{abstract}

\section{ま えがき}

小児大腿骨頸部骨折は，成人特に老人の場合と異な り稀な骨折であると考えられる．松田によると，全大 腿骨頸部骨折の $1 \%$ 内外に過ぎないという．私達の教 室での 頻度は，過去 14 年間における全大腿骨頸部骨 折 158 例中 15 才以下の本骨折は 10 例 6.33 \%であり, これは 15 才以下の小児患者, 総数 16849 名中 $0.06 \%$ を亦めるに過ぎない。

また，一般に小児骨折が機能的あるいは解剖学的予 後が良好であるのに反し，後発合併症として骨頭壊 死, 内反股等を招き治療成績が不良なるものが多いと されている。

私達は，本骨折に対して非観血的治療が行なわれた 9 症例を経験したので, 特にその治療成績について考 察を加えてみたい.

$$
\text { 症例 }
$$

ここに報告する症例は, 昭和 29 年から昭和 43 年 6
月までに 熊大整形外科を訪れた 小児大腿骨頸部骨折 10 例のうち, 非観血的治療が行なわれ, 治療後 5 力月 以上を経過した 9 症例である.とれらの症例を一括し てみると第 1 表の如くである. このうち，症例 4,5 は陳旧例で来院時既に骨頭の変形がみられ, 他の 7 症 例は新鮮例である(第 1 表).

\section{治 療 成 継}

治療後 5 カ月以上を経過している 9 例について,レ 線像，股関節機能，および歩行能力を調査した。 その 結果は次の如くである. 即ち, 骨療合は全例 5 力月以 内に認められ，骨頭壊死および骨頭変形は症例 $3 ， 4$ に出現をみている. 内反股に関しては, 症例 1,5 は 頸体角が健側と較べ約 $10^{\circ}$ 内反し, 症例 $2 ， 3 ， 4$ で は約 $20^{\circ}$ 内反がみられた. 股関節機能では, 外転, 開 排，回旋制限を症例 $3 ， 4$ 亿認め，下肢短縮は症例 4 に $3 \mathrm{~cm}$ ，症例 5 に $2 \mathrm{~cm}$ みられた。 また，症例 4 に は, 軽度の跛行をみ, その「レ」線上では, 変形性股 関節症の像がみられた. 歩行痛や疲労感等は全例訴え 
第 1 表

\begin{tabular}{|c|c|c|c|c|c|c|c|c|}
\hline 症例 & 年令 & 性 & 左右 & 受傷 機転 & 骨 折 型 & 療 & 荷重時期 & 受傷後年数 \\
\hline 1 & 8 & 우 & 右 & 交 通 事 故 & 中 間 部 & $\begin{array}{l}\text { 1. 外転肢位皮引 } 32 \mathrm{~d} \\
\text { 2. Whitman's Cast } 3 \mathrm{~m}\end{array}$ & $5 \mathrm{~m}$ & $5 \mathrm{~m}$ \\
\hline 2 & 14 & 우 & 左 & $\begin{array}{l}\text { 加速度のついた } \\
\text { もよりの転落 }\end{array}$ & " & $\begin{array}{l}\text { 1. 外転肢位牽引 } 44 \mathrm{~d} \\
\text { 2. Whitmast } 70 \mathrm{~d} \\
\text { 3. 兔荷 装 具 } 21 \mathrm{~d}\end{array}$ & $8 \mathrm{~m}$ & $2 y$ \\
\hline 3 & 8 & s & 左 & 交 通 事 故 & 転 子 間 & $\begin{array}{l}\text { 1. 外転肢位牽引 } 16 \mathrm{~d} \\
\text { 2. Whitman's Cast } 79 \mathrm{~d}\end{array}$ & $3 \mathrm{~m}$ & 3 y $5 \mathrm{~m}$ \\
\hline 4 & 8 & s & 左 & $\begin{array}{l}\text { 転 倒時 石で } \\
\text { 大転子部を打撲 }\end{array}$ & " & $\begin{array}{l}\text { 1. 外転肢位牽引 } 32 \mathrm{~d} \\
\text { 2. Whitman's Cast } 2 \mathrm{~m}\end{array}$ & $3 \mathrm{~m}$ & $5 y$ \\
\hline 5 & 10 & 우 & 右 & $\begin{array}{l}\text { 加速度のついた } \\
\text { もよりの転落 }\end{array}$ & " & $\begin{array}{l}\text { 1. 外転肢位牽引 } 64 \mathrm{~d} \\
\text { 2. 免荷装具 }(43 \text { 日後より) }\end{array}$ & $\begin{array}{l}\text { 免荷装具に } \\
\text { て歩行中 }\end{array}$ & $5 \mathrm{~m}$ \\
\hline 6 & 2 & s & t & $\begin{array}{l}\text { 転 倒 時 } \\
\text { 大転子部を打撲 }\end{array}$ & 転子貫通 & Whitman's Cast $56 \mathrm{~d}$ & $2 \mathrm{~m}$ & $1 \mathrm{y} 1 \mathrm{~m}$ \\
\hline 7 & 3 & $\hat{\delta}$ & 左 & 交 通 事 故 & " & $\begin{array}{l}\text { 1. 外転肢位育引 } 20 \mathrm{~d} \\
\text { 2. Whitman's Cast } 21 \mathrm{~d}\end{array}$ & $2 \mathrm{~m}$ & 3 y $7 \mathrm{~m}$ \\
\hline 8 & 6 & 우 & 右 & $\begin{array}{l}\text { 加速度のついた } \\
\text { あのりの転落 }\end{array}$ & " & 外転肢位引 $42 \mathrm{~d}$ & $3 \mathrm{~m}$ & $3 y$ \\
\hline 9 & 9 & $\hat{o}$ & 右 & 高所ょりの唒落 & " & $\begin{array}{l}\text { 1. 外転肢位牽引 } 24 \mathrm{~d} \\
\text { 2. 徒手整復 } \\
\text { Whitm, }\end{array}$ & $3 \mathrm{~m}$ & $11 \mathrm{y}$ \\
\hline
\end{tabular}

ていない.

以上の結果を 1 年以上経過した 7 症例について成績 を判定すると，良好 5 例，不良 2 例である。

\section{考按}

治療法については，小児の本骨折が稀であり，しか も後発合併症が多岐であるためか, 報告者により見解 の相異がみられる。即ち, Colonna, Carrell は外転 肢位での率引やWhitman's cast での非観血的治療 法を推学し, Allende は骨折傾斜角 (Pauwels 角) が $50^{\circ}$ 以下の時は非観血的治療法を, $50^{\circ}$ 以上の時は観 血的治療法を行なうとし, Mc Dougall は非観血的治 療法と内固定に上る観血的治㙩法の治療成績には差は ないと述べている. また Ratliff は 10 才以下で転位が あるものには初めから Osteotomy を行なうという。 本報告例では，非観血的治療法が行なわれたが，それ は小児の本骨折は老人之較へ保存的整復が比較的容易 であり, かつ, 骨新生力が著しく早期に骨湶合を期待 し得うるてとと，観血的治療法によつて加えられる組 織の損傷や頸部骨㽞有内血行の荒廃の危険をさけるため である.

小児大腿骨頸部骨折の治療成績は Mc Dougall に よると 24 例中成績良好なるもの 8 例, 不良 16 例,
Ratliff は 71 例中良好 31 例, 不良 39 例といい, 本 報告では 7 例中良好 5 例，不良 2 例であつた。 しか し, 骨折型别にみると転子貫通骨折は 4 例中良好 4 例 で非常に良いが，中間部および転子間骨折は 3 例中不 良 2 例と悪い. かように, 本骨折の治寮成績が思わし くないのは併発する，i）骨頭壊死および骨頭変形, ii）変形性股関節症, iii）股関節運動制限, iv) 内反 股，v）下肢短縮等の合併症によるものである．なか でも骨頭壊死および骨頭変形の発生率は高いとされ, 著者も昨年臨床整形外科に $43.15 \% \pm 4.10 \%$ で成人に 比し高いととを示した。本報告例では， 7 例中 2 例に その発生をみている. 骨折部位と骨頭壊死出現との関 係については, 成人では中間部骨折時に出現すると云 われているが，小児では Ratliff 等の報告の如く転子 間骨折時でもその発生をみる. 私達の骨頭壊死を起て した 2 症例は共に転子間骨折であつた．まれ；骨頭壊 死の出現時期は骨折後大体 1 年前後とされているが, 症例 3 は 2 年後に, 症例 4 では 1 年半後に初めて「レ」 線像にて骨頭核の不正形，陥凹化および濃影を発見さ れている.だが， 2 症例ともそれ以前より骨頭壊死の 状態を起としていたと考えられ，骨折処置後少なくと も $1 \sim 2$ 年の間は $1 \sim 3$ カ月毎に「レ」線観察を行な 


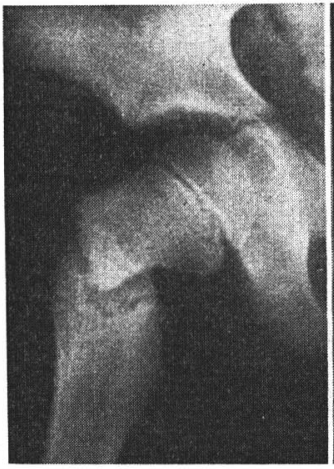

症例 4 転子間骨折 (受傷時)
変形性股関節症 ( 5 年後)

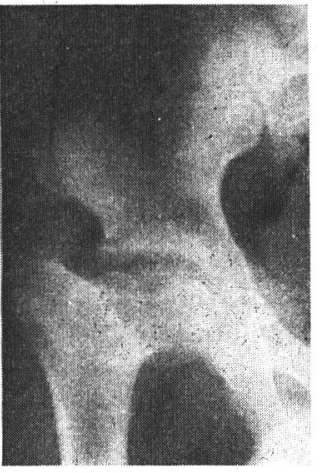

図 1

い骨頭の濃影化等を示標とし早期発見につとめなけれ ばならないと感じる。ま，骨頭壊死の経過は，症例 3 では受傷後 3 年半を経過した現在, 骨頭核の変形は 修復されつつある.しかし, 症例 4 では 5 年後の現 在, 変形性股関節症の状態に進展している (図1).

内反股は，下肢短縮の原因となり，またCarrellら は, 内反股に対し骨頭壊死を予防するため Ostectomy を行なつて 変形を正すべきだと主張している． 鶴海 は, 內反股発生は整復不良, 或いは整復位保持の失敗 によると述べている，私達の症例中，健側と較べ頸体 角が減少し内反を呈しているものについてみると, 満 足な整復および固定が得られずに正しい頸体角の保持 が出来なかつたためと, 正しい钼体角の保持が出来て も荷重時期が早期に失したためとの 2 つの原因が考え られる。

下肢短縮については，Mc Dougall は成長停止まで に4〜 5 インチの短縮を生じるとし, 鶴海は 4 例に 1 $\sim 3 \mathrm{~cm}$ の短縮を認めている. 下肢短縮の程度は受傷 時の年令や骨格の成長状態によつて異なるが, 私達の 症例では 2 症例に $3 \mathrm{~cm}$ および $2 \mathrm{~cm}$ の患肢短縮をみ ている．その原因として，症例 4 は内反股および骨頭 変形のためであると思われ，症例 5 では健側と較べ約 $10^{\circ}$ 内反はみられるが，第三骨片を有する骨折であり むしろ骨片の瘠合状況のためと考光られる.

かかる治療成績を悪くする後発合併症の出現に, 骨 折の正確な整復および 固定はもちろんのととである が，荷重開始時期も重要な因子をなすものと考えられ る. 荷重開始時期については, 例え内固定がなされて も長期間荷重の禁止をなすべきだとする意見が多く，
松田等は, 完全なる体重負荷は 6 力月から 1 年以後が 妥当であるとしている，私達の治燎成績からみると， 転子貫通骨折は 3 力月間の免荷で後発合併症を認めな いので充分であらうと思える。しかし，転子間骨折 は, 3 力月の免荷では 2 症例とも骨頭壊死などの後発 合併症を認め不充分である. 中間骨折および転子間骨 折では，外傷の程度わよび拡り，また力学的関係が転 子貫通骨折より骨折の治瘾並びに変形の出現予防に不 利であると考えられるので，荷重時期の決定は慎重で なければならない。即ち、本例では少なくとも6力月 以上の免荷が必要であると思われる．事実，8力月間 免荷した症例では，内反股をみるが，骨頭壊死および 変形はみられなかつた（図2）.

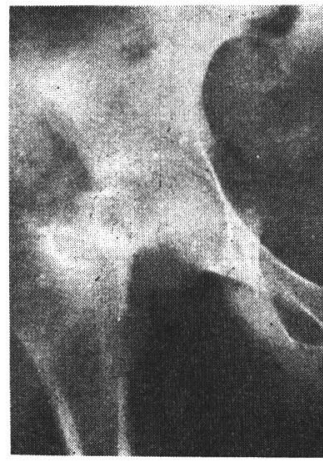

症例 2 中間部骨折 (受傷時)

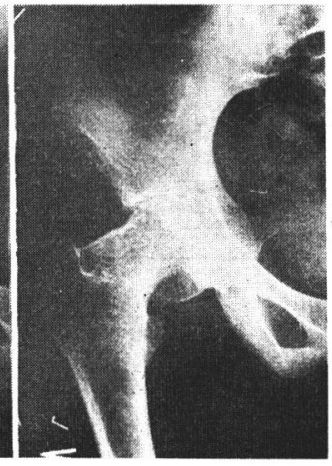

骨頭壊死及び変形(一) ( 2 年後)
図 2

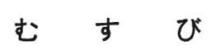

1) 本骨折は比較的稀な骨折である. 即ち熊大整形 外科における小児外来 (15才以下) 総数の僅か $0.06 \%$ であり，全大腿骨頚部骨折のうち，15才以下のものは $6.33 \% \pm 1.93 \%$ である.

2 ）保存的治療を行ない 1 年以上経過した 7 症例の うち, 骨頭壊死抢よび骨頭変形がみられたものは 2 症 例である。このうち, 1 症例は変形性股関節症に進展 した。

3）また, 他の後発合併症として内反股, 下肢短 縮，股関節運動制限，跛行などがみられた。

4） 1 年以上経過した治療成績は，良好 5 例，不良 2 例である，骨折型別にみると，転子貫通骨折は全例 良好な成績であるが，中間および転子間骨折は 3 例中 不良 2 例となり，その成績は悪い。 
5 ）治療成績を左右する一つの因子として, 荷重開 始時期は重要な因子であり，中間部および転子間骨折 では少なくとも 6 カ月以上の免荷が必要であると思え る.

御指導, 御校閲を睗つた玉井達二教授に深謝する。

\section{考文 献}

1）小児骨折の治療：糟谷清一郎著.

2）忽那竜雄：臨床整形外科. $2: 2,1967$.

\section{発言留米大 宮城 成圭} 小児大服骨頸部内側骨折の治癨は全例に起とるが， 術後の搰頭 および 頻部の変化は 高頻度に 起てつてく る. 発生予防に免荷が重要であるという演者の意見に
賛成するが実際上に免荷をさせるととが困難である．

$$
\text { 啠閔熊本大 玉井 達二 }
$$

宮城先生に質問

(1)小児の場合いつから荷重を開始されたか.

(2)骨頭に 異常が 1 年半位でも出てくるとのととだ が, 何時頃から異常が想められるか.

回答留米大 宮城成圭

具体的に免荷の方法を原則的に述べると，私の教室 では内固定後 1 週より股, 滕の関節運動（自動的）を 開始し，3カ月より支杖歩行，その後は出来るだけ

（少なくとも 1 年間）長期支杖歩行を続けるよう指導 している.

\title{
膝 蓋 骨 脱 $⿴$ 曰 治 療 経 験 \\ 鳥取赤十字病院 整形外科

上山 奎 自 内 田利 高
福 嶋 泰夫 大 月 健 二

\section{Lateral Dislocation of the Patella}

By

\author{
K. Ueyama, T. Uchida, \\ Y. Fukushima \& K. Otsuki \\ Division of Orthopedic Surgery, Tottori Red Cross Hospital
}

\begin{abstract}
Dislocation of the Patella appears to be rare and is almost always to the lateral not to the medial side.
1) Three cases of traumatic lateral subluxation are discribed. In one of these underdevelopment of the lateral femoral condyle is presented. There was no history of injury. In all cases the knee was immobilized for 3 weeks with a plaster splint.

2) Two cases of recurrent dislocation is presented. Tavernier's technique for a boy and Campbell's technique for a girl were practiced.

When five cases were last seen from three to fourteen months after treatment the patella was stable and flexion of the knee full.
\end{abstract}

滕蓋骨脱曰は比較的稀で, 多くは外方脱白である. 外傷性外方脱臼, 習慣性脱臼, 恒久性脱臼とに分類さ れているが，なかでも習慣性脱臼の原因は不明な場合 が多く, 定説はない，我々は最近外傷性外方脱臼 3 例，習慣性外方脱田 2 例を経験した。前者は非観血的 に，後者は観血的に治療し，ほぼ満足すべき結果を得

たので報告する．

症例

症例 1 15 才の女子.

主訴：左滕関節の伸展不能と痛み.

家族歴：特記すべきものはない。 